\title{
A Tentative Proposal to Use Orthodox Theological Relational Selfhood as an Alternative for Confucian-Influenced Chinese Evangelicals
}

\author{
Tsung-I Hwang (D)
}

Citation: Hwang, Tsung-I. 2021. A Tentative Proposal to Use Orthodox Theological Relational Selfhood as an Alternative for Confucian-Influenced Chinese Evangelicals. Religions 12: 321. https://doi.org/10.3390/ rel12050321

Academic Editors: Bradley Nassif and Tim Grass

Received: 18 March 2021

Accepted: 27 April 2021

Published: 1 May 2021

Publisher's Note: MDPI stays neutral with regard to jurisdictional claims in published maps and institutional affiliations.

Copyright: (C) 2021 by the author. Licensee MDPI, Basel, Switzerland. This article is an open access article distributed under the terms and conditions of the Creative Commons Attribution (CC BY) license (https:/ / creativecommons.org/licenses/by/ $4.0 /$ )
T. I. Hwang's Cross Theology Classroom, Puli 545, Taiwan; mtsungih@gmail.com

Abstract: Eastern Orthodox Christianity and Chinese evangelicals have rarely interacted. Even if it seems that Eastern Orthodox Christianity and its theology have hardly influenced Chinese evangelicals in the past, this article demonstrates the possibility that Orthodox theology can still indirectly transform Confucian-influenced Chinese evangelicals. Moltmann, a great contemporary Protestant theologian, is influenced deeply by Stăniloae, a great modern Eastern Orthodox theologian, particularly in the development of social trinitarian theology in Eastern Orthodox heritage. Moltmann argues that social trinitarian anthropology can prevent the social and individual problems appeared in the societies shaped by either individualism or collectivism. Selfhood is one academic language used to discuss this relationship between the self and society. Despite modernization and westernization, contemporary Chinese people are still deeply influenced by Confucian models of relational selfhood. Even for Chinese evangelicals who had converted years ago, their way of thinking and behavior might be as much Confucian as biblical. The Confucian-influenced collectivist mindset may lead to problematic selfhood and more challenging interpersonal relationships. This article uses Orthodox theology via Moltmann's social trinitarian, Stăniloae-inspired approach to develop an alternative relational selfhood for contemporary Chinese Christians.

Keywords: Moltmann; Stăniloae; Eastern Orthodox; Chinese evangelicals; collectivism; social trinitarian anthropology; Confucian-influenced/Ru-influenced; repressed form of self; relational selfhood

\section{Introduction}

The Orthodox Christian church is the third-largest Christian faith in the world. However, it Orthodox Christians are an exceedingly small minority among Chinese Christians, living in Mainland China, ${ }^{1}$ Hong Kong, Macau, or Taiwan. Only about $0.015 \%$ of Christians in this area, and $0.02 \%$ among evangelicals, identify as members of an Orthodox church (Mandryk 2010, pp. 215-16, 252-53, 256, 259). Consequently, Orthodox Christianity and its theology are very alien to Chinese evangelicals. There is hardly direct contact between the Orthodox church and Chinese evangelicals. However, Orthodox influence can still occur in an indirect way. Applying the findings of the author's PhD thesis (Hwang 2018) to further development and research, this paper will introduce a tentative proposal to show how Orthodox theology can still indirectly influence Confucian-influenced Chinese evangelicals. This proposal is about how social trinitarian theology, in the Eastern Orthodox heritage (Mosser 2009, p. 132), is transmitted from Dumitru Stăniloae (1903-1993), through Jürgen Moltmann (1926-), and then can be applied to transform the Confucian/Ruinfluenced selfhood of Chinese evangelical Christians. In this article, Ruism/Confucianism, $\mathrm{Ru} /$ Confucian, Ruist/Confucianist, and Ruification/Confucianization refer to the same tradition or set of traditions. Confucianism and related terms are sometimes seen as a mistranslation of a larger cultural, philosophical, and religious tradition, emphasizing the personhood of Confucius. By contrast, the Chinese word for the term, $r u$, is much broader and more inclusive. Therefore, in the contemporary, or post-traditional, context, where Ruinspired Chinese is broader, the term Ruism/Ruist, rather than Confucianism/Confucian, 
serves as a more pertinent and helpful description. Besides, it is notable that some parts of the explanation and description of the proposal in this paper are given in a brief synopsis. The author's exploration in greater depth and longer discussion with comprehensive interdisciplinary references can be seen in his previous works.

\section{How and in Which Area Moltmann Was Influenced by Stăniloae}

\subsection{Who Is Jürgen Moltmann?}

Jürgen Moltmann is a world-famous and influential German (evangelical) Reformed theologian who is currently a professor emeritus at the University of Tübingen. He was once the pastor of the Evangelical Church of Bremen-Wasserhorst (Neal 2009, p. 368), the editor of the periodical Evangelische Theologie (Moltmann 2009, p. 201), and the president of the Society for Evangelical Theology in Germany (Moltmann 2009, p. 254), and was conferred the first honorary doctorate by the Nicaraguan Evangelical University (Moltmann 2009 , p. 370). However, he is not viewed as an evangelical theologian by all evangelical theologians, mainly Anglophonic ones (Chung 2012a), due to his "ecumenical", "revisionist", and "liberationist" theological position (Chung 2012b, p. 1; Buxton 2012, p. 65). (Confusing things further is the fact that the German term Evangelical is often used generically to describe Protestants.) Undoubtedly, as indicated in his autobiography, A Broad Place (Moltmann 2009), and his Experiences in Theology (Moltmann 2000) — the summary of his journey of theology-Moltmann does not confine his theological discussion to the area of evangelical theology. He is not only open to engaging ecumenically with traditional theologies from both Eastern Orthodox and Roman Catholic churches but is also willing to discuss questions from a great variety of contemporary theologies, including charismatic theology, liberation theology, and public theology. Although Moltmann's evangelical status is beyond the scope of this paper, his theology has influenced evangelicalism, especially Chinese evangelicals, because more than fifteen of his books have been translated and published in Chinese, mainly by the evangelical publishers in Taiwan and Hong Kong.

Besides his famous work Theology of Hope (Moltmann 1967) and his prominent eschatology, Moltmann is, in particular, a contemporary pioneer in the Latin-based Church tradition, including Catholic and Protestant Churches, in paying attention to the social trinitarian doctrine - whose model of the Trinity "begin[ning] with God's threeness, defines the divine essence generically, and is fond of multi-person social analogies of the Trinity" (Mosser 2009, p. 132), is highly valued in the Eastern Orthodox Church tradition due to its "rejection of filioque" (Nalunnakkal 2005, p. 11)-and extending it to develop his interpretations of relational selfhood (Grenz 2001, p. 16). Moltmann (1981, p. 189) traced this concept of social Trinity back to "the Cappadocian doctrine of the Trinity". Although there are other contemporary scholars who also argue for the social model of the Trinity, their interpretations vary considerably. Besides, Moltmann is one of the few based on the doctrine of the imago Dei, and social trinitarian theology develops a comprehensive and profound social trinitarian anthropology in his interpretation, in which the eschatological perspective of his social Trinitarian theology is very essential in the "becoming" dimension of human selfhood (Moltmann 1981, p. 216f). Furthermore, Moltmann might be the only social trinitarian theologian who engages himself in understanding Chinese culture and dialoguing with Daoism and Ruism in his works (Moltmann 1989, pp. 87-101, 1998, 2008b).

\subsection{Who Is Dumitru Stăniloae?}

Dumitru Stăniloae was appreciated by both Moltmann and other Western theologians and Orthodox theologians as one of the modern greats in Orthodox theology (Juhász 1979, p. 752; Moltmann 2014, p. 37; Toma 2014, pp. 12-16; Munteanu 2015, pp. 25-32). The main task of this Romanian theologian, the late professor at the Theological Institute of Bucharest (Juhász 1979, p. 752), was to promote patristic theology, namely early Christian theology during the first five centuries, establishing "contemporary neo-patristic theology," namely, "a creative return to the patristic theology" (Croitoru 2019, p. 89), and producing "existential personalism" and "neo-patristic revival" in both Orthodox and the Western 
theologies (Louth 1997, pp. 261-62; Toma 2014, pp. 10, 16), and confront with and solve man's modern problems (Juhász 1979, p. 747). As "a link between East and West" by bridging "the cultural gap" between them with "trinitarian spirituality" (Toma 2014, pp. 14-15, 21-22; Munteanu 2015, pp. 30, 32), his significant contribution to both western and orthodox theologies is of Trinitarian, Pneumatological, ecumenical, ecological, and trinitarian anthropological theology (Stăniloae 1994, pp. 53-78, 2000, pp. 65-112, 2012; Miller 2000, pp. 25-54; Bordeianu 2010; Munteanu 2015, pp. 26-27).

\subsection{The Influence of Stăniloae on Moltmann's Development of Social Trinitarian Theology}

Compared to Moltmann, Dumitru Stăniloae is not as world-famous and influential as Moltmann. However, his influence on Moltmann is second only to Karl Barth (Moltmann 2014, p. 30). Moltmann had engaged in the ecumenical movement as a member of the World Council of Churches (WCC) since 1963. Through attending the Klingenthal Conferences of 1978 and 1979 on the "filioque" problem in the doctrine of the Trinity (Moltmann 2014, pp. 30-36), ${ }^{2}$ he and Stăniloae began a fifteen-year journey of deep friendship-like son and father, as Moltmann describes - and theological conversation (Moltmann 2014, p. 30). Thanks to Stăniloae, Orthodox theology became more and more important for Moltmann in the second half of his life. As a result, Moltmann is convinced that Western theology will still be able to learn a great deal from this wonderful Eastern theology of its own (Moltmann 2014, p. 30).

Influenced by Stăniloae's richer trinitarian understanding of the coming of the Holy Spirit than the controversial "filioque" formula could provide, the theologians in the Klingenthal Conferences reached an agreement to recommend that the Western churches delete the "filioque" from the creed and that both Eastern and Western theologians continue to work to develop the trinitarian mystery of God (Moltmann 2014, pp. 34-35). Based on this new insight, Moltmann then developed a "social doctrine of the Trinity" in his The Trinity and the Kingdom of God: The Doctrine of God (Moltmann 1981) - its original German version was published in 1980 (Munich: Chr. Kaiser). Later, he developed a "holistic pneumatology" under the title The Spirit of Life: A Universal Affirmation (Moltmann 1992)—its original German version was published in 1991 (Munich: Chr. Kaiser).

The most important foundation of Moltmann's social trinitarian doctrine is based on Patristic theologians' understanding of the concept of "the sociality of the three divine Persons", namely perichoresis-divine communion (Moltmann 1981, p. 198, emphasis original, thereafter, "eo"). This is also what Staniloae emphasizes in his doctrine of the Trinity, from which he develops his theology of love (Stăniloae 1994, chp. Ten; Moltmann 2014 , p. 37). The author finds that this insight into perichōrēsis keeps Moltmann's social triune God distinguishable and distinctive from either God as three modes of being or God as the supreme substance. He (Moltmann 2008a, pp. 372-75) pinpoints three indispensable elements in the perichoretic existence and relationships between the three persons of the Triune God: unity; diversity; and equality (non-hierarchical symmetry). ${ }^{3}$ Based on this foundation and Christology, Moltmann develops first his concept of the "open Trinity" to interpret the gracious relationship between the Triune God and sinful humans (Moltmann 1977, pp. 55, eo; 1981, pp. 90-96; 1985, p. 242). Through the doctrine of the image of God based on the doctrine of social Trinity and his open Trinity, he establish his comprehensive social trinitarian anthropology to interpret the perichoresis-oriented interpersonal relationships among human persons, derived from a functional template - the image of the Trinity: the perichoretic relationships between the three persons of the Triune God (Stăniloae 1980, p. 36; Moltmann 1985, pp. 215-43). Unity, diversity, and equality (non-hierarchical symmetry) are also the elements of such a community, and this community is an "open community" -namely "open friendship" in Moltmann's term (Moltmann 1978, pp. 50-63) —and a community of grace in the author's term-namely, "the Community of the Free" in Moltmann's term (Moltmann 1981, pp. 198-211). ${ }^{4}$

It is notable that Moltmann (1990, pp. 269-71, 1992, p. 254) presents his trinitarian theological anthropology as an alternative synthesis between collectivism (prevailing more 
in Eastern Asian countries)_-where the self tends to be soluble in relationships-and individualism (dominating more in Western Anglo-European countries)—where the self tends to be autonomous and separate.

There is more evidence to show that Moltmann's interpretations of social trinitarian doctrine are inspired or influenced by Orthodox theology/Stăniloae. For example, Moltmann's usage of the term "inter-subjectivity" to describe the divine unity (Stăniloae 1980, p. 94; 1994, pp. 260-78; Moltmann 2008a, p. 374). Moltmann's explanation of the Divine personal differences also shows this influence: "the very difference of the three Persons lies in their relational, perichoretically consummated life process" (Stăniloae 1980, p. 258; Moltmann 1981, p. 175). In addition, when Moltmann refers to humans' intimacy with God in terms of the Eastern Orthodox emphasis on theosis (Moltmann 1985, pp. 228-29), especially as the ground for liberation from "the pressure of the world," he relies on Stăniloae's claims (Moltmann 1985, pp. 228-29; Charry 1998, p. 106; Stăniloae 2000, pp. 89, 191-200).

\section{Problematic Selfhood and Interpersonal Relationships Appears in Confucian-Influenced Chinese Evangelicals}

Relational ethics dominates almost all the codes of conduct, interpersonal relationships, and value systems in post-traditional Ru-influenced Chinese societies. ${ }^{5}$ Since the 1970 s, the problem of selfhood and social repression has been seen as contributing to "personality disorders or other psychological and social problems" (Wong 2001, pp. 2, 24, 31), including suicide (Zhang et al. 2004, pp. 431, 435-36). ${ }^{6}$ This has been identified as a product of Ruist relational ethics in a growing number of non-Ruist scholars' studies. ${ }^{7}$ These include both theoretical and empirical research, produced in the realm of interdisciplinary social science studies, including, but not limited to, (socio-)psychological, sociological, historical, (psychological) anthropological, medical, and even business studies. ${ }^{8}$ Drawing from and integrating the findings in an extensive literature review of these studies, the author, in another journal article (Hwang 2017, p. 105), adopted the phrase "repressed form of self" to integrate and describe a common critique, by scholars, of the Ruist self in post-traditional Ru-influenced Chinese societies.

This problem is produced in post-traditional $\mathrm{Ru}$-influenced Chinese contexts of a relational selfhood resulting from some Ruist cultural elements: familism (Ru-based collectivism), an ingrained Ru-influenced hierarchical social structure, the absence of transcendent external creator God, and a strong ideology and practice of moral self-cultivation (Hwang 2018, pp. 41-63). Although this problematic selfhood and these causative Ruist elements have been identified by social science studies since the 1970s, some notable post-traditional Ruists, such as Weiming Tu (1985, p. 13), do not regard this problematic selfhood as the product of orthodox Ruist traditions or as native to orthodox Ruism. It is interesting that, although the New Ruist Weiming Tu (1976, pp. 52-54) criticizes the problem of collectivism, in a general sense, like those scholars, what he advocates for is actually a self with the same problematic characteristics. In his Ruist understanding, social roles are assigned, individual autonomy and subjectivity are restrained, and dominance is asserted. In other words, Tu's account of New Ruist relational selfhood fails to disprove scholarly critics regarding Ru-based collectivism. His so-called orthodox Ruist version of relational selfhood is essentially the same as the version criticized by social science scholars in post-traditional Ru-influenced contexts. For example, Tu (1985, pp. 8-9) maintains that the distinctions between self and society are unimportant in traditional Chinese or post-traditional Ruist thinking because he (Tu 1985, p. 82, eo) argues that the boundary between "individual and society" should vanish, and even the usage of the word "self" as well as first person pronouns should be "reconsidered". Hall and Ames (1998, p. 42), Hawaii Ruists describe this similar vision of Ruist selfhood in detail: ${ }^{9}$

In the classical Chinese language, there is no distinction between the first person singular, $I$, and the first person plural, we. An $I$ is always a we. Equally significant $\ldots$ is the absence ... of any explicit and consistent distinction between the subjective $I / w e$ and the objective me/us. The $I / w e$ is embedded in the me/us. 
Even if such an assertion can be criticized as being too over-generalized and reductionist, it is still noted as a claim that requests some serious consideration. This is exactly one of the reasons Xuewei Zhai 翟學偉 (Zhai 2010, p. 204) offers for why there are very few studies focusing on the Chinese self. ${ }^{10}$ He generalizes that, in comparison with "the Western one," "the Chinese individual self" is not as emphasized or important as a Chinese cultural characteristics, and so is not considered to be worthy of study (ibid.). ${ }^{11}$ However, it is notable that this problematic selfhood and the problem it produces is not unique to, but fortified in, Ru-influenced cultural contexts.

Ruification/Confucianization is a quite common phenomenon among contemporary Chinese, even Christians, because contemporary Chinese people and societies are still consciously and unconsciously influenced by Ruism. This phenomenon also appears among other East Asian Christians (Koh 1996; Oh 2003, p. 132; Lee 2006). The Ruification phenomenon of Christians' values, mindsets, and behavioral modes includes legalistic readings of scripture, emphasizing moral teachings and admonitions in sermons. In these scholars' readings, this leads to a "repressed form of the self", problematic lack of individuation, and interpersonal relationship problems. These predominate in Ruinfluenced Chinese Christian evangelical contexts due to Ruification. These observations are echoed in the work of many scholars. Confirmations are found in works by Cheming Tan 陳濟民 (Tan 1988, pp. 18-21), Andrew Chiu 丘恩處 (Chiu 1999, pp. 222-23), Fènggăng Yáng 楊鳳崗 (Yáng 2004), and Leechen Tsai 蔡麗貞 (Tsai 2014, p. 205), as well as foreign scholars and missionaries, such as Wright Doyle $(2006,2011)$, Jackson Wu (2011b), and Wendell W. Friest (2013, p. 199).This is a relatively new approach and only two studies by Chinfen Yu 余錦芬 and Yuting Huang 黃郁婷 (Yu and Huang 2009) and Zhuōjiā Lǐ 李卓 嘉 (Ľ 2013) involve the Ruification phenomenon among Chinese evangelical Christians. Both verify the existence of this phenomenon. However, these shared observations still need further development through the use of relevant ethnographic studies. ${ }^{12}$ It is notable that the Ruification of Christianity has become a political means to restrain and control the development of Christianity in Mainland China in its new religious policy, initially formulated by Jìnpíng Xí 習近平 in 2016 (Song 2016).

Accordingly, social trinitarian anthropology is offered as a potential alternative to relational selfhood, which is quite new to Chinese evangelical Christians, ${ }^{13}$ and might benefit post-traditional Ru-influenced Chinese, including Ru-influenced Chinese evangelical Christians.

\section{How Social Trinitarian Anthropology Has Been Engaged in Transforming Ru-Influenced Chinese Evangelicals}

After affirming the Ruist predicament in this problem through critically analyzing Tu Weiming's interpretation of Ruism, the author's theoretical study explores Moltmann's Christian social trinitarian account of relational selfhood to see whether, or to what extent, it can be a potential alternative solution to the problem of the repressed form of self in post-traditional Ru-influenced Chinese through a comprehensive analysis of the essential distinctness in Tu's and Moltmann's presuppositions and claims.

According to Moltmann's interpretation of social trinitarian anthropology, one's identity is made secure by gracious moral cultivation, ${ }^{14}$ moral transformation by Christ's saving and transforming grace, in contrast to Ruist moral transformation by oneself, namely, moral self-cultivation, granted by the triune God but not by moral self-cultivation, so as to earn worthiness of social relationships. Besides this, in Moltmann (1992, p. 259, eo) interpretation, "the moral purpose of changing the world", which is the ultimate purpose of achievement-oriented Ruist moral cultivation (Tu 1990, pp. 74, 123, 177), is not considered as "the motive" for gracious moral cultivation. Instead, it expresses how the triune God made itself "wide open for the others" (Moltmann 1992, p. 259, eo). Therefore, Tu's moral self-cultivation and Moltmann's gracious moral cultivation are two essentially different life-transforming approaches, which exclude each other. The author succinctly summarizes Moltmann's gracious moral cultivation in this way. 
The realization of a real self for any person is by the promise, grace, and works of the triune God, through the embedded imago Dei [(image of God)], namely the imago Trinitatis [(image of Trinity)]. This is God's work within human beings, a messianic redeeming and reconciling imago Christi [(image of Christ)], promising a hope for the transforming gloria Dei [(glory of God)] that is fulfilled for future fellowship with God and others in Christ (Moltmann 1981, 1985).

That is to say, Moltmann's social trinitarian account of relational selfhood is based on humans' status as both being, namely existent, and becoming, namely transformable, as the imago Trinitatis. The author further highlights the concrete difference between these two moral cultivations in practice.

In Moltmann's account of gracious moral cultivation, wisdom, holiness, and morality are the outcomes of a renewed image and likeness of God, bestowed to human beings in the New Creation. In contrast, in Tu's accounts of traditional and post-traditional Ruist ethics, it is promoted that they are the outcomes of pursuing moral self-cultivation through ceaseless activity. However, the outcomes are unattainable and unrealistic idealism, as the other New Ruist Shuhsien Liu (1987, pp. 228-30) admits.

As mentioned above, the community in Moltmann's social trinitarian account is "an open community of grace. According to the perichoresis-oriented template from God's social trinitarian relationships, this community is framed within its relationship with the open Trinity. Accordingly, this open community cultivates open relational selves, namely an orientation towards ontological equality among individuals in relation, a dynamic balance between the diversity of each individual and the unity of the community. Although in the functional social order of that community, each individual has their different duties and roles, they are ontologically equal. As a result, sincere and appropriately assertive expressions of self, mutual respect and submission, as well as direct and effective communication, can happen in such a community. Therefore, such a community also provides ways to overcome manipulative, demanding, coercive, co-dependent, hurting, and broken interpersonal relationships. Besides, in addition to a relational foundation, the absolute and objective value of the self in this open community is grounded in an external transcendent reference point-the triune God, instead of society, as in Tu Weiming's Ruist account.

Therefore, by offering relational options that do not demand a repressively socially imposed idealized morality, such a community is helpful to reveal the true person, without the continual need for negative masking, and so is able to liberate the repressed form of the self.

Although scholars such as Bellah (1980 and 1982, cited in Tu 1990, p. 8) are concerned with the problems caused by both individualism and collectivism, an individual person is undoubtedly never impervious to his/er own communal relationships, in which s/he is always embedded. Therefore, Moltmann's social trinitarian anthropology, as a special synthesis of the good elements of both individualism and collectivism, might fulfill this universal hope among scholars. The problems of the repressed form of self among post-traditional Ru-influenced Chinese Christians are closely related to problems of their personal development, especially before their conversion. It can be found that Moltmann's account of relational selfhood might nurture a transforming vision for personal development within Ru-influenced familial and communal settings. Consequently, Moltmann's theoretical approach might also provide a foundation for counselling, transformative psychology, and integrative psychotherapy, so as to liberate individuals and communities suffering from repressive social impositions.

In sum, in facing to the problem of a repressed form of self among post-traditional $\mathrm{Ru}$ influenced Chinese evangelical Christians, Moltmann's Christian social trinitarian account of relational selfhood offers a concrete and promising alternative solution. It then becomes possible to liberate the repressed form of self and replace repressive social impositions with Moltmann's open relational options. The beneficial contribution of social trinitarian anthropology to post-traditional Ru-influenced Chinese, including Chinese evangelical Christians, is argued for because it provides a solution to liberating the repressed form of 
self by developing and cultivating a different "relational selfhood." For Chinese evangelical Christians, the social trinitarian doctrine is not intended to replace their current trinitarian theology but to enrich it, because they need a Christian theological "relational selfhood."

In the proposal this paper presents, Moltmann's social trinitarian account of relational selfhood is proposed as an alternative solution to the repressed form of self that occurs in post-traditional Ru-influenced Chinese, including evangelical Christians. This shows how Orthodox theology can indirectly help to transform Ru-influenced Chinese evangelicals via Moltmann's Stăniloae-inspired approach. Undoubtedly, will take time to see how much Orthodox theology will influence Chinese evangelicals, and further empirical research is needed to verify how beneficial this social trinitarian anthropology will be for Ru-influenced Chinese evangelical Christians.

\section{Conclusions}

Eastern Orthodox Christianity and Chinese evangelicals have rarely interacted. Even if it seems that Eastern Orthodox Christianity and its theology have little influenced Chinese evangelicals in the past, the author's study forms a tentative proposal for how Orthodox theology can still indirectly transform Ru-influenced Chinese evangelicals through Dumitru Stăniloae's influence on Jürgen Moltmann.

In the same way, Orthodox theology might, through Moltmann's social trinitarian anthropology of relational selfhood, influence contemporary Ru-influenced Japanese, Korean, and Vietnamese evangelicals.

Funding: This research received no external funding.

Conflicts of Interest: The authors declare no conflict of interest.

\section{Notes}

1 Most Orthodox Christians and churches are mainly in "Heilongjiang, Inner Mongolia, Xinjiang minority regions or Beijing" of Northern China due to the mission work of Russian Eastern Orthodox churches (Wang 2013, pp. 15-16).

2 This term filioque literally means "and from the Son" (Bromiley 1984, eo). In order to defend themselves against Arians, the Latin Western churches first added this phrase into the Nicene Creed (325) at the Council of Toledo in 589 to emphasize that "the Holy Spirit proceeds from the Father and the Son", stressing "the perfect equality between the Son and the Father" in their full deity (Dulles 1995, pp. 31-32; Edgar and Oliphint 2009, p. 16). However, this was not the agreement made within the confessions at Nicaea (325) and Constantinople (381) but that "the Holy Spirit proceeds from the Father" (Dulles 1995, pp. 31-32). As a result, this insertion was rejected by the Greek Eastern churches (Bromiley 1984), who also opposed Arianism (Blaising 1984), but insisted on stressing the full deity of the Holy Spirit (Moltmann 1981, p. 181). This main doctrinal bifurcation led to the great schism between the Eastern Orthodox Church and the Western Roman Catholic Church in 1054 and has never been resolved officially with binding declarations (Moltmann 1981, pp. 178-80; 2014, pp. 35-36; Pless 2005, p. 116f; Siecienski 2010; New World Encyclopedia 2017).

3 It is noted that some other social trinitarian theologians, for example, Zizioulas (1995, pp. 50-55), interpret the three persons of God as a community of asymmetrical hierarchy (Volf 1998, pp. 76-81).

4 In the Eastern Orthodox theological tradition, theological anthropology is also based on a social trinitarian theology with these three elements: "person (hypostasis) ... communion (koinonia)", and "nature (ousia)" (Bates 2012). However, for Moltmann (1981, pp. 188-89), it still supports a trinitarian structure of asymmetrical hierarchy because the Father is the "sole origin" of both the Son and the Holy Spirit (Zizioulas 1995, pp. 50-55; 2004, p. 45; Volf 1998, pp. 76-81). Insisting on the concept of "equally primary", Moltmann (1981, pp. 188-202) criticizes both the accounts of the Latin church tradition and the Eastern church tradition, which support "clerical monotheism" and "political monotheism" and have asymmetrical trinitarian structures.

5 The phrase post-traditional Ru-influenced Chinese is adopted in this paper to avoid the problem of ambiguity and generalization. The word "Ruism/Confucianism" is an ambiguous term, which can include a range of historical and contemporary meanings. This paper follows the general approach of Lauren Pfister (2015). Post-traditional Ru-influenced Chinese in this paper denotes "the small folk tradition" still influencing contemporary Chinese, as described by Shuhsien Liu 劉述先 (1934-2016) (Liu 1996a, p. 92), a contemporary New Ruist. This tradition that has existed for centuries and has been influenced by the other two main traditions, "the great tradition of the Ruist 
refined intellectual spirit" and "the tradition of the Way expressed in politicized Ruism," is the mental habits and behavioural customs of most common Chinese people from ancient times to the present. It indicates looser and wider meanings of Ruism that cannot be interpreted by ordinary people themselves but must be done by researchers (Liu 1996b, p. 85). Confucianism or Ruism is often listed as part of the constellation of the three teachings (Buddhism, Daoism Confucianism), which are sometimes used as a shorthand for Chinese religions.

6 See also Jie Zhang et al. (2009, p. 187), Jie Zhang (2010, pp. 323-24), Jie Zhang et al. (2010, pp. 581-84), Fei Wu (2011a, pp. 213-19), Zhang and Li (2012, pp. 659-60), Yingyeh Chen et al. (2012, p. 139), Hyeon Jung Lee (2012), and Jie Zhang (2014, pp. 146, 151-52).

7 The term non-Ruist scholars, used in this paper, denotes those scholars whose academic disciplines are not mainly Ruist studies regardless of their ethnicity or nationality.

8 For example, Winnicott (1965, p. 133), June Ock Yum (1988, p. 386), Stephen K. K. Cheng (1990, p. 510), and Zhèngbó Zhèng 鄭正博 (Zheng 1990, p. 172). Due to the limitation of space and the focus of this paper, many other references to social science scholars and their relevant findings are not listed and discussed here. They can be found in detail in Tsung-I Hwang (2018, chp. Two and Appendix E).

9 Ames (2006, p. 520) states that the Ruist self is not an individualized self.

10 See also Zhongfang Yang (1991a, pp. 48-49; 1991b, p. 95) and Jiādòng Zhèng 鄭家棟 (Zheng 2003, p. 63).

11 See also Yiyin Yang (2008, p. 152) and Wenberng Pong 彭文本 (Pong 2009, p. 77).

12 There are many discussions on this phenomenon within the realm of contextual theology; a few notable examples among many include: Paul Fong 封尚禮 (Fong 1967, p. 50f, 79-81, 297), Willard G. Oxtoby (1933-2003) (Oxtoby 1983), Weiming Tu (1985), Toynbee and Ikeda (1989), Ching and Küng (1993, pp. 279-83), Thong and Fu (2009), Băoluó Huáng 黄保羅 (also as Paulos Huang) (Huang 2011), and David Marshall (2012).

13 Social trinitarian doctrine is not taught in most Chinese-speaking theological seminaries. Therefore, most Chinese evangelical ministers do not know it, let alone Chinese evangelical lay-Christians.

14 The author coined the phrase gracious moral cultivation to denote and explain the Christian theology of life-transforming development from imago Christi, in contrast with Ruist life transformation by oneself (moral self-cultivation) though moral cultivation is not a Christian theological term.

\section{References}

Ames, Roger T. 2006. Zìwǒ de Yuánchéng: Zhōngxī Hùjìngxià de Gǔdiăn Rúxué yǔ Dàojiā 《自我的圓成 : 中西互鏡下的古典儒學與道家》 (Self-Consummation: Classical Confucianism and Daoism within the Mirror of East and West). Edited and Translated by Guóxiáng Péng 彭國翔. Shijiazhuang: Héběi Rénmín (河北人民).

Bates, Dana. 2012. A Trinitarian Framework for Transformative Praxis. Draft of a Public Lecture at Gordon College. Wenham: Gordon College.

Blaising, Craig A. 1984. Nicaea, Council of (325). In Evangelical Dictionary of Theology. Edited by Walter A. Elwell. Grand Rapids: Baker, pp. $774-75$.

Bordeianu, Radu. 2010. Filled with the Trinity: The Contribution of Dumitru Stăniloae's Ecclesiologoy to Ecumenism and Society. Journal of Eastern Christian Studies 62: 55-85. [CrossRef]

Bromiley, Geoffrey W. 1984. Filioque. In Evangelical Dictionary of Theology. Edited by Walter A. Elwell. Grand Rapids: Baker, p. 415.

Buxton, Graham. 2012. Moltmann on Creation. In Jürgen Moltmann and Evangelical Theology: A Critical Engagement. Edited by Chung Sungwook. Eugene: Wipf \& Stock, pp. 40-68.

Charry, Ellen T. 1998. The Crisis of Modernity and the Christian Self. In A Passion for God's Reign: Theology, Christian Learning and the Christian Self. Edited by Miroslav Volf. Grand Rapids: William B. Eerdmans, pp. 89-112.

Chen, Yingyeh, Kevin Chien-Chang Wu, Saman Yousuf, and Paul S. F. Yip. 2012. Suicide in Asia: Opportunities and Challenges. Epidemiologic Reviews 34: 129-44. [CrossRef]

Cheng, Stephen K. K. 1990. Understanding the Culture and Behaviour of East Asians-A Confucian Perspective. Australian and New Zealand Journal of Psychiatry 24: 510-15. [CrossRef] [PubMed]

Ching, Julia, and Hans Küng. 1993. Christianity and Chinese Religions. London: Student Christian Movement.

Chiu, Andrew 丘恩處. 1999. Yóutài Wénhuà Chuántǒng yǔ Shèngjīng 《猶太文化傳統與聖經》. (Jewish Cultural Tradition and the Bible). New York: New York Theological Education Centre (紐約神學育中心).

Chung, Sungwook, ed. 2012a. Jürgen Moltmann and Evangelical Theology: A Critical Engagement. Eugene: Wipf \& Stock.

Chung, Sungwook. 2012b. Moltmann on Scripture and Revelation. In Jürgen Moltmann and Evangelical Theology: A Critical Engagement. Edited by Sungwook Chung. Eugene: Wipf \& Stock, pp. 1-16.

Croitoru, Ion Marian. 2019. Patristic and Neopatristic Theology? Periods of Patrology in the Church Life. Icoana Credintei 5: 79-96. [CrossRef]

Doyle, Wright. 2006. Cultural Factors Affecting Chinese Church Leaders; Global China Center I Analysis. Available online: http: // tinyurl.com/jzb8zn2 (accessed on 30 January 2016). 
Doyle, Wright. 2011. Doyle Prayer Update: English-Speaking Churches. [E-mail] Message to T I. Hwang (mtsugnih@gmail.com). Sent Friday 17 June 2011, 17:52. Available online: http:/ / tinyurl.com/h5erb9x (accessed on 17 June 2011).

Dulles, Avery. 1995. The Filioque: What Is at Stake? Concordia Theological Quarterly 59: 31-47.

Edgar, William, and K. Scott Oliphint, eds. 2009. Christian Apologetics Past and Present: A Primary Source Reader (Volume I, to 1500). Wheaton: Crossway.

Fong, Paul 封尚禮. 1967. Zhōngguó Wénhuà de Zhèng Făn Hé《中國文化的正反合》. (Thesis Antithesis Synthesis · These[s] Antithese[s] Synthese[s] · of Chinese Culture).. Hong Kong: Dōngyà Lìshǐ Wénhuà Yánjiū Huì (東亞歷史文化研究會 Association of Historical Culture in East Asia).

Friest, Wendell 傅立德. 2013. Shàngdì de Dànéng: Fúyīn ShénxuéJīchǔ 《上帝的大能 : 福音神學基礎》. (The Power of God: [The Foundation of Cross Theology]). Taipei: Dàoshēng (道聲).

Grenz, Stanley J. 2001. The Social God and the Relational Self: A Trinitarian Theology of the Imago Dei. Louisville: Westminster John Knox.

Hall, David L., and Roger T. Ames. 1998. Thinking from the Han: Self, Truth, and Transcendence in Chinese and Western Culture. Albany: State University of New York Press.

Huang, Paulos 黃保羅. 2011. Hànyǔ Suǒyǐn Shénxué-Duì Fàguó Yēsūhuìshì Xù Jiăng [Matteo Ricci] zhīhòu Wénmíng Duìhuà de Yánjiū 〈漢語索隱神學一對法國耶穌會士續講利瑪賔之後文明對話的研究〉 (Sino-Christian Academic Figurist Theology: An Analysis of the Cultural Dialogical Attempt by Some French Jesuits in Following the Footprints of Matteo Ricci). Shēnzhèn Dàxué Xuébào (Rénwén Shèhuì Kēxué Băn) 《深圳大學學報 (人文社會科學版)》[Shenzhen University Journal: HumanitiesEsocial sciences version] 2: 5-11.

Hwang, Tsungi 黃宗儀. 2017. Chūtàn Hòuchuántǒng shòu Rújiā Qǔfā de Huárén Guānxìxìng Zìwǒguān de Diănfàn Zhuănhuàn 〈初 探後傳統受儒家啓發的華人關係性自我觀的典範轉換〉 (An Exploration of a Paradigm Shift for the Post-Traditional Ru-Inspired Chinese Relational Selfhood). Táiwān Shénxué Lùnkān 《台灣神學論刊》 (Taiwan Journal of Theology) 44: 97-133.

Hwang, Tsungi 黃宗儀. 2018. Liberating the Repressed Form of Self in Post-Traditional Ru-Influenced Chinese: A Theoretical Study of the Responses of Tu Weiming and Jürgen Moltmann. Ph.D. Thesis, Oxford Centre for Mission Studies (Collaborated with Middlesex University), Oxford, UK. Available online: http:/ / eprints.mdx.ac.uk/25899/ (accessed on 12 December 2018).

Juhász, István. 1979. Dumitru Staniloae's ecumenical studies as an aspect of the Orthodox-Protestant dialogue. Journal of Ecumenical Studies 16: 747-64.

Koh, Byongik. 1996. Confucianism in Contemporary Korea. In Confucian Traditions in East Asian Modernity: Moral Education and Economic Culture in Japan and the Four Mini-Dragons. Edited by Weiming Tu. Cambridge: Harvard University Press, pp. 191-201.

Lee, Helen. 2006. Healthy Leaders, Healthy Households 1: Challenges and Models. In Growing Healthy Asian American Churches. Edited by Peter Cha, Kang S. Steve and Lee Helen. Downers Grove: InterVarsity Press, pp. 58-76.

Lee, Hyeon Jung. 2012. Modernization and Women's Fatalistic Suicide in Post-Mao Rural China: A Critique of Durkheim. In Chinese Modernity and the Individual Psyche. Edited by Andrew B. Kipnis. New York: Palgrave Macmillan, pp. 149-65. Available online: http:/ / public.eblib.com/choice/publicfullrecord.aspx?p=1109270 (accessed on 24 May 2017).

Lǐ, Zhuōjiā 李卓嘉. 2013. Huárén Chuántǒng Wénhuà Qíngjìngxià de Táiwān Jīdūjiào Jiātíng Jiàoyăng Jīngyàn zhī Yánjiū /華人傳統文 化情境下的台灣基督教家庭教養經驗之研究〉. (Study on the Taiwan Christian Parenting Experience in the Context of Chinese Traditional Culture). Master's thesis, Soochow University (東吳大學), Taipei, Taiwan.

Liu, Shuhsien 劉述先. 1987. Lùn Rújiā 'Nèishèng Wàiwáng' de Lǐxiăng 〈論儒家「内聖外王」的理想〉 [On the Confucian Ideal of 'Inner Sageliness and Outer Kingliness']. In Rújiā Lúnlǐ Yántǎohuì Lùnwénji 《儒家倫理討會論文集》. Edited by Shuhsien Liu 劉述先. [Conference on Confucian Ethics]. Singapore: Dōngyà Zhéxué Yánjiūsuǒ (東亞哲學究所), pp. 218-31.

Liu, Shuhsien 劉述先. 1996a. Confucian Ideals and the Real World: A Critical Review of Contemporary Neo-Confucian Thought. In Confucian Traditions in East Asian Modernity: Education and Economic Culture in Japan and the Four Mini-Dragons. Edited by Weiming Tu. Cambridge: Harvard University Press, pp. 92-112.

Liu, Shuhsien 劉述先. 1996b. Dāngdài Zhōngguó Zhéxué Lùn: Rénwù Piān 《當代中國哲學論 : 人物篇》. [Discussion of Contemporary Chinese Philosophy: On Figures]. River Edge: Bāfāng (八方).

Louth, Andrew. 1997. The Orthodox Dogmatic Theology of Dumitru Staniloae. Modern Theology 13: 253-67. [CrossRef]

Mandryk, Jason. 2010. Operation World: The Definitive Prayer Guide to Every Nation, 7th ed. Colorado Springs: Biblica Publishing.

Marshall, David. 2012. Discussion on the God in Confucianism. [Conversation]. St Philip and St James Church, Woodstock Road, Oxford, OX2 6HR, Oxford Centre for Mission Studies. Personal communication, February 14.

Miller, Charles. 2000. The Gift of the World: An Introduction to the Theology of Dumitru Stăniloae. Edinburgh: T \& T Clark.

Moltmann, Jürgen. 1967. Theology of Hope: On the Ground and the Implications of a Christian Eschatology. Translated by James W. Leitch. London: Student Christian Movement.

Moltmann, Jürgen. 1977. The Church in the Power of the Spirit: A Contribution to Messianic Ecclesiology. Translated by M. Kohl. London: Student Christian Movement.

Moltmann, Jürgen. 1978. The Open Church: Invitation to a Messianic Life-Style. Translated by M. Douglas Meeks. London: Student Christian Movement.

Moltmann, Jürgen. 1981. The Trinity and the Kingdom of God: The Doctrine of God. Translated by Margaret Kohl. London: Student Christian Movement.

Moltmann, Jürgen. 1985. God in Creation: An Ecological Doctrine of Creation. Translated by Margaret Kohl. London: Student Christian Movement. 
Moltmann, Jürgen. 1989. Creating a Just Future: The Politics of Peace and the Ethics of Creation in a Threatened World. Translated by John Bowden. London: Student Christian Movement.

Moltmann, Jürgen. 1990. The Way of Jesus Christ: Christology in Messianic Dimensions. Translated by Margaret Kohl. Minneapolis: Fortress.

Moltmann, Jürgen. 1992. The Spirit of Life: A Universal Affirmation. Translated by Margaret Kohl. Minneapolis: Fortress.

Moltmann, Jürgen. 1998. Christianity and the Revaluation of the Values of Modernity and of the Western World. In A Passion for God's Reign: Theology, Christian Learning and the Christian Self. Edited by M. Volf. Grand Rapids: William B. Eerdmans, pp. $23-43$.

Moltmann, Jürgen. 2000. Experiences in Theology: Ways and Forms of Christian Theology. Translated by M. Kohl. Minneapolis: Augsburg Fortress.

Moltmann, Jürgen. 2008a. God in the World—the World in God: Perichoresis in Trinity and Eschatology. In The Gospel of John and Christian Theology. Edited by Richard Bauckham and Carl Mosser. Grand Rapids: William B. Eerdmans, pp. 369-81.

Moltmann, Jürgen. 2008b. [Moltmann] Lùn Zhōngguó Wénhuà 《莫特曼論中國文化》 (Jürgen Moltmann on Chinese Culture). Translated by Zhàomíng Dèng 鄧肇明, and Niànyuè Céng 曾念粵. Hong Kong: Jĩdào (基道).

Moltmann, Jürgen. 2009. A Broad Place: An Autobiography. Translated by Margaret Kohl. Minneapolis: Fortress.

Moltmann, Jürgen. 2014. Dumitru Stăniloae im ökumenischen Kontext. International Journal of Orthodox Theology 5: $29-40$.

Mosser, Carl. 2009. Fully Social Trinitarianism. In Philosophical and Theological Essays on the Trinity. Edited by Thomas H. McCall and Michael C. Rea. Oxford: Oxford University Press, Oxford Scholarship Online, pp. 131-50.

Munteanu, Daniel. 2015. Dumitru Staniloae's Influence on Jurgen Moltmann's Trinitarian and Ecological Theology. International Journal of Orthodox Theology 6: 24-52.

Nalunnakkal, George Mathew. 2005. Come Holy Spirit, Heal and Reconcile: Called in Christ to Be Reconciling and Healing Communities. International Review of Mission 94: 7-19. [CrossRef]

Neal, Ryan A. 2009. Jürgen Moltmann (1926-). In The Blackwell Companion to the Theologians. Edited by Ian S. Markham. Chichester: Blackwell, vol. 2, pp. 367-84.

New World Encyclopedia. 2017. Filioque Clause. New World Encyclopedia. Available online: https://tinyurl.com/y8djrn5p (accessed on 22 December 2020).

Oh, Myungseon. 2003. Study on Appropriate Leadership Pattern for the Korean Church in Postmodern Era. Journal of Asian Mission 5: 131-45.

Oxtoby, Willard G. 1983. The Meaning of Other Faiths. Philadelphia: John Knox.

Pfister, Lauren F. 2015. Christian Diversity in China during the Past 200 Years: Post-Secular Visions and Their Scholarly Significance. Lecture. Easton: Lafayette College, April 14, Available online: http:/ / tinyurl.com/zpkldlh (accessed on 4 January 2017).

Pless, John T. 2005. Tracking the Trinity in Contemporary Theology. Concordia Theological Quarterly 69: 99-117.

Pong, Wenberng 彭文本. 2009. Tang Chunyi Lùn 'Gètř de Zìwǒ’〈唐君毅論「個體的自我」〉 (Theory of Individuality of Chunyi Tang). Zhéxué yǔ Wénhuà 《哲學與文化》[Philosophy and Culture] 36: 77-100.

Siecienski, A. Edward. 2010. The Filioque: History of a Doctrinal Controversy. New York: Oxford University Press.

Song, Jun 宋軍. 2016. Dàxìn Wúwèi-Nèidì Zōngjiào Zhèngcè Xīndòngxiàng jì Jiàohuì de Yùbèi 《大信無畏一内地宗教政策新動向暨教會的 預備》. (Fearlessness with Great Faith-New Trends of Religious Policies in Mainland China and Preparations for the Church). Public Lecture. Hong Kong: China Graduate School of Theology, September 26, Available online: http:/ / tinyurl.com/y7fxcthf (accessed on 30 June 2020).

Stăniloae, Dumitru. 1980. Theology and the Church. Translated by Robert Barringer. Crestwood: St. Vladimir's Seminary Press.

Stăniloae, Dumitru. 1994. The Experience of God: Orthodox Dogmatic Theology Vol.1 Revelation and Knowledge of the Triune God. Translated by Ioan Ionita, and Robert Barringer. Brookline: Holy Cross Orthodox.

Stăniloae, Dumitru. 2000. The Experience of God: Orthodox Dogmatic Theology, Vol.2, the World: Creation and Deification. Translated by Ioan Ionita, and R. Barringer. Brookline: Holy Cross Orthodox.

Stăniloae, Dumitru. 2012. The Holy Trinity: In the Beginning There Was Love. Translated by Roland Clark. Brookline: Holy Cross Orthodox.

Tan, Cheming 陳濟民. 1988. Rènshí Jiějīng Yuánlǐ 《認識解經原理》. (Understanding Principles of Biblical Interpretation). Taipei: Campus Evangelical Fellowship (校園).

Thong, Chankei, and Charlene L. Fu. 2009. Finding God in Ancient China: How the Ancient Chinese Worshiped the God of the Bible. Grand Rapids: Zondervan.

Toma, Ştefan L. 2014. Father Dumitru Stăniloae (1903-1993) and his Contribution to Theology: Recognitions and Commentaries. Review of Ecumenical Studies Sibiu 6: 8-27. [CrossRef]

Toynbee, Arnold, and Daisaku Ikeda. 1989. Choose Life: A Dialogue. Edited by Richard L. Gage. New York: Oxford University Press.

Tsai, Leechen 蔡麗貞. 2014. Shuí Shuō Zìjù Jiào Rén Sǐ: Cóng Shìjīngshǐ Kàn Diănfàn de Zhuănyí 《誰説字句叫人死 : 從釋經史看典範的轉 移》. (Who Says the Letter Kills: The Paradigm Shift in Hermeneutics). Taipei: Campus Evangelical Fellowship (校園).

Tu, Weiming. 1976. Centrality and Commonality: An Essay on Chung-Yung. Honolulu: The University Press of Hawaii.

Tu, Weiming. 1985. Confucian Thought: Selfhood as Creative Transformation. Albany: State University of New York Press.

Tu, Weiming. 1990. Confucian Thought: Selfhood as Creative Transformation. 4th Printing. Albany: State University of New York Press.

Volf, Miroslav. 1998. After Our Likeness: The Church as the Image of the Trinity. Grand Rapids: William B. Eerdmans.

Wang, John Z. X. 2013. Christianity in China Today. Journal of the Interdisciplinary Study of Monotheistic Religions (JISMOR) 8: 15-25. 
Winnicott, Donald W. 1965. The Maturational Processes and the Facilitating Environment: Studies in the Theory of Emotional Development. 64 vols. London: The Hogarth Press and the Institute of Psycho-Analysis The International Psycho-Analytical Library.

Wong, Melvin W. 2001. Chinese Culture and Psychological Disorders in Pastoral Ministry: An Introduction to the Core Issues [Class handouts] December 2001. Hong Kong: Hong Kong Baptist Theological Seminary, December 20.

Wu, Fei. 2011a. Suicide, a Modern Problem in China. In Deep China: The Moral Life of the Person, What Anthropology and Psychiatry Tell us about China Today. Edited by Kleinman Arthur, Sing Lee, Everett Zhang, Jun Jing and Yunxiang Yan. Berkeley: University of California Press, pp. 213-36. [CrossRef]

Wu, Jackson. 2011b. Authority in a Collectivist Church: Identifying Crucial Concerns for a Chinese Ecclesiology. Global Missiology English 1. Available online: http:/ / ojs.globalmissiology.org/index.php/english/article/view/679 (accessed on 28 March 2018)

Yáng, Fenggang 楊鳳崗. 2004. Sānwèi Jīdū: Quánqiú Shìyězhōng de Zhōnghuá Wénhuà yǔ Jīdūiiāo〈三味基督 : 全球視野中的中華文 化與基督教〉 [Three-Flavoured Christ: A Global Perspective of Chinese Culture and Christianity]. Shànghăi Dàxué Xuébào (Shèhuì Kēxué Băn) 《上海大學學報 (社會科學版)》 [Journal of Shanghai University (Social Science Edition)] 11: 111-12.

Yang, Yiyin 楊宜音. 2008. Guānxìhuà Háishì Lèibiéhuà: Zhōngguórén ‘Wǒmén' Gàiniàn Xíngchéng de Shèhuì Xīnlǐ Jīzhì Tàntǎo 〈關係化還是類別化：中國人「我們」概念形成的社會心理機制探討〉 (Categorization or Guanxilization: The Social Psychology Mechanism of the Chinese Concept of 'Us'). Zhōngguó Shèhuì Kēxué《中國社會科學》 (Social Sciences in China) 4: 148-59.

Yang, Zhongfang 楊中芳. 1991a. Huígù Găngtái 'Zìwǒ' Yánjiū: Fănxǐng yǔ Zhănwàng/回顧港台「自我」研究：反省與展望〉 [Reviewing the study of 'the self'in Hong Kong and Taiwan: Introspection and Outlook]. In Zhōngguórén •Zhōngguóxīn: Réngé yǔ Shèhuì Piān 《中國人•中國心 : 人格與社會篇》. [Chinese People • Chinese Heart: Personality and Society]. Edited by Zhongfang Yang 楊中芳 and Shangren Gao 高尚仁. Taipei: Yuănliú (遠流), pp. 15-92.

Yang, Zhongfang 楊中芳. 1991b. Shìlùn Zhōngguórén de 'Zijì' Lǔlùn yǔ Yánjiū Fāngxiàng 試論中國人的「自己」理論與研究方向〉 [On the Theory and Research Directions of Chinese People's 'Self']. In Zhōngguórén •Zhōngguóxīn: Réngé yǔ Shèhuì Piān 《中 國人•中國心 : 人格與社會篇》. [Chinese People • Chinese Heart: Personality and Society]. Edited by Zhongfang Yang 楊中芳 and Shangren Gao 高尚仁. Taipei: Yuănliú (遠流), pp. 93-145.

Yu, Chinfen 余錦芬, and Yuting Huang 黃郁婷. 2009. Fùmǔ Zōngjiào Xíngwéi yǔ Qīngshàonián Qīnzǐ Guānxì zhī Yánjiū-Yĩ Taipei Jīdūjiào Jiātíng wéi Lì $\langle$ 父母宗教行為與青少年親子關係之研究一以台北市基督教家庭為例〉(Religious Behavior of Parents and Parent-child Relationships among Adolescents from Christian Families in Taipei City). Huágāng Nóngkē Xuébào《華岡農科學報》 (Hwa Kang Journal of Agriculture) 23: 35-59. [CrossRef]

Yum, June Ock. 1988. The Impact of Confucianism on Interpersonal Relationships and Communication Patterns in East Asia. Communication Monographs 55: 374-88. [CrossRef]

Zhai, Xuewei 翟學偉. 2010. Zhōngguórén de Liănmiàn Guān: Xíngshì Zhǔyì de Xīnlǐ Dòngyīn yǔ Shèhuì Biăozhēng 《中國人的臉面觀 : 形式主義的心理動因與社會表徵》. (Perspectives on Chinese 'Face': Psychological Motives and Social Representations [of Formalism]). Beijing: Peking University Press (北京大學出版社).

Zhang, Jie, and Ziyao Li. 2012. Characteristics of Chinese Rural Young Suicides by Pesticides. International Journal of Social Psychiatry 59: 655-62. [CrossRef]

Zhang, Jie, Yeates Conwell, Liang Zhou, and Chao Jiang. 2004. Culture, Risk Factors and Suicide in Rural China: A Psychological Autopsy Case Control Study. Acta psychiatrica Scandinavica 110: 430-37. [CrossRef] [PubMed]

Zhang, Jie, Nini Dong, Robert Delprino, and Li Zhou. 2009. Psychological Strains Found from In-Depth Interviews With 105 Chinese Rural Youth Suicides. Archives of Suicide Research 13: 185-94. [CrossRef]

Zhang, Jie, William Wieczorek, Yeates Conwell, X. M. Tu, B. Y. W. Wu, Shuiyuan Xiao, and C. Jia. 2010. Characteristics of Young Rural Chinese Suicides: A Psychological Autopsy Study. Psychological Medicine 40: 581-89. [CrossRef] [PubMed]

Zhang, Jie. 2010. Marriage and Suicide among Chinese Rural Young Women. Social Forces 89: 311-26. [CrossRef]

Zhang, Jie. 2014. The Gender Ratio of Chinese Suicide Rates: An Explanation in Confucianism. Sex Roles 70: 146-54. [CrossRef]

Zheng, Jiadong 鄭家棟. 2003. Zhōngguó Chuántǒng Sīxiǎngzhōng de Fùzǐ Guānxì jí Quánshì de Miànxiàng一Cóng ‘Fù wèi Zi Yĩn, Zi wèi Fù Yĩn' Shuōqĩ 〈中國傳統思想中的父子關係及詮釋的面向一從「父為子隱，子為父隱」説起〉 [The Father-Son Relationship and Interpretative Dimension in Chinese Traditional Thought-Based on 'the Father Conceals the Misconduct of the Son, and the Son Conceals the Misconduct of the Father']. Zhōngguó Zhéxuéshǐ 《中國哲學史》 [Chinese Philosophic History] 1: 55-63.

Zheng, Zhengbo 鄭正博. 1990. Zhōngguórén Dāngrán Búshēngqì 〈中國人當然不生氣〉 [Chinese People Do Not Certainly Get Angry]. In Zhōngguórén de Shìiān Yóuxì: Rénqing yǔ Shìù 《中國人的世間遊戲: 人情與世故》. [Chinese People's World Game: Favor in Relationship and the Ways of the World].. Edited by The Editorial Board of Zhānglăoshī Yuèkān《張老師月刊》編輯部. Taipei: Zhānglăoshī (張老師), pp. 167-76.

Zizioulas, John D. 1995. The Doctrine of the Holy Trinity: The Significance of the Cappadocian Contribution. In Trinitarian Theology Today: Essays on Divine Being and Act. Edited by Christoph Schwöbel. Edinburgh: T \& T Clark, pp. 44-60.

Zizioulas, John D. 2004. Being as Communion: Studies in Personhood and the Church. London: Darton Longman and Todd. 